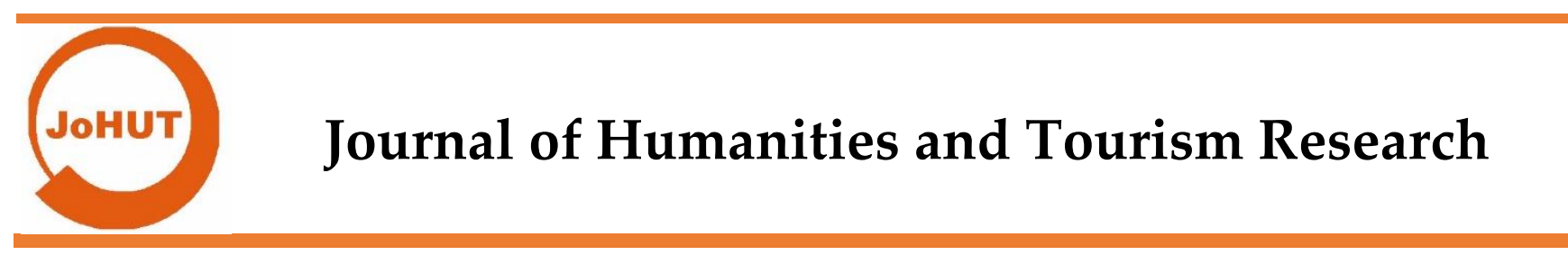

Derleme

\title{
Türkiye'nin Günümüz Doğu Akdeniz Politikaları
}

\author{
Turkey, the Eastern Mediterranean Politics Today
}

Aydın Adnan Menderes Üniversitesi, İletişim Fakültesi, Aydın, Türkiye

\section{ORCID}

T.A.: 0000-0001-6391-3905

Corresponding Author:

Turan AKKOYUN

Email: turan.akkoyun@hotmail.com

Citation: Akkoyun, T. (2020). Türkiye'nin Günümüz Doğu Akdeniz Politikaları. Journal of Humanities and Tourism Research, 10 (2), 414-431.

Submitted: 20.05 .2020

Accepted: 01.06.2020

\section{Turan AKKOYUN}

$\ddot{O z e t}$

Ülkeler arasında amansız bir rekabet ve yarış ara vermeksizin sürmektedir. Hemen her kıta ve bölgede farklı amaçlar doğrultusunda hissedilen rekabet, taraf ülkeler haricindeki ülkeleri hatta dünyanın tamamın doğrudan etkilemekte, diğer sahalardaki ekonomik, siyasi, uluslararası hukuk, diplomatik tutum ve davranışların şekillenmesine, yepyeni rekabet konularına sebep olmaktadır. Doğu Akdeniz uluslararası rekabetin güncel sahası araştırmanın konusu olarak seçilmiştir. Türkiye'nin geleceği açısından son derece önem arz eden Doğu Akdeniz; İtalya, Slovenya, Horvatistan, Bosna-Hersek, Karadă̆, Arnavutluk, Yunanistan, Türkiye, Suriye, Lübnan, İsrail, Filistin, Mısır, Libya, Tunus kıyılarıyla çevrilidir. Yakın geçmişe dayanan bilhassa 2009 yılından sonra "İsrail, Lübnan, Kıbrıs ve Suriye" gibi sahadaki doğalgaz arama, tespit, üretim, transfer faaliyetleri, coğrafyadaki önceki ve sonraki hareketlenmeler dikkat çekmektedir. Dünyanın gündemine yerleşen Doğu Akdeniz'de kıyısı bulunan Türkiye, Yunanistan, Güney Kıbrıs Rum Kesimi, İsrail, Lübnan, Mısır karşı karşıya gelmiştir. Suriye'nin mevcut durumunda bu mevzuuyla ilgilenecek gücü bulamamaktadır. Ülkelerin sadece isimleri ve yakın geçmişte yaşadıklarını araştırma konusuna bağlamak bilimsel olarak mümkün görünmektedir.

Anahtar Kelimeler: Doğu Akdeniz, Tarih, Doğal Gaz, Türkiye.

\section{Abstract}

A relentless race continues without interruption between the countries. The competition, pursued for different purposes in each continent and region, has international and even global consequences: economic, political, legal, and diplomatic attitudes and behaviors are affected, causing new issues. This study addresses international competition in the Eastern Mediterranean. Of great importance for Turkey is the Eastern Mediterranean: Italy, Slovenia, Croatia, Bosnia and Herzegovina, Montenegro, Albania, Greece, Turkey, Syria, Lebanon, Israel, Palestine, Egypt, Libya and Tunisia, surrounded by coast. Natural gas exploration, detection, production and transfer in fields such as "Israel, Lebanon, Cyprus and Syria" after 2009 as well as previous and future movements in the region stand out. The global agenda to solve issues in the Eastern Mediterranean, including the coast with Turkey, Greece, South Cyprus, Israel, Lebanon and Egypt, came across. In the current situation of Syria; it cannot find the power to deal with this issue. With the names of the countries only and their experiences in the recent past, it is scientifically possible to link to the subject of research.

Keywords: Eastern Mediterranean, History, Natural Gas, Turkey. 


\section{GİRİş}

Birey, toplum ve devlet. Her biri diğerinin varlığıyla anlam kazanmaktadır. Aynı şekilde her biri yükseliş zamanları kadar duraklama, çöküş, yok olma gibi durumlarla da karşı karşıya kalmaktadır. Aslında birindeki olumlu gelişmenin diğerine sirayeti adalete, nizama, liyakata, kadim değerlere verilen önemle doğru orantılı iken, olumsuz gelişmeler kendiliğinden domino etkisiyle süratlenip diğerlerinin gidişatını hemen tesir edebildiği gözlemlenmektedir. "Tuzaklara düşmeyen, başarılı eleştirel düşünmenin temel taşı" doğru anlamaktır. ${ }^{1}$ "Gelişmiş ülkeler arasında amansız bir rekabet ve yarış vardır. Bu yarışa teknolojik yarış da denebilir. Bu savaşta kazanmak için söz konusu ileri ülkeler iki önemli kaynağını yani beyin gücü ve parasını, Araştırma + Geliştirmeye ayırmaktadırlar."2 İlerlemek isteyen, ilerlemeyi göze alan bir yapının bunun haricinde hareket etmesi mümkün değildir. Bu noktada araştırmacının "halen olayların içinde yaşamakta olması"3 akademik sorumluluğunu, hassasiyetini daha da artırmakta, diğer bilim dallarına katkılar sağlamaktadır.

1789 Fransız Devrimi başladığında bunu ülkenin iç meselesi gibi görüp tarafsız ${ }^{4}$ kalanlar, yanıldıklarını anlama fırsatı dahi bulamadan, "artık hiçbir şeyin eskisi gibi olmadığının" sonuçlarını göremeden dünyadan göçüp gitmişlerdir. Ortaya çıan yeni fikirler, daha 1787 Amerikan Anayasasi'nın rotasını belirleyen yeni bir güç kaynağı yani "para" ile harmanlanınca "rasyonelleşmiş, iyi hesaplanmış, bencil isteklerinin engelleri"5 kaldırılmış, kadim değerlerin pınarları da kurutulmuş oluyordu. Bundan böyle idealler, susuzluktan çölde kavrulan bireyin aslında hiç olmayan serap ile buluşmasındaki geçici mutlulukların aldatıcı sarhoşluklarından ileri gidemiyordu. "Gösterişli makro-ekonomik çözümler"6 sürdürülebilir olmayıp, aktarımdaki zıt yönlü propaganda ${ }^{7}$ usulleri güzergahları birbirine karışabilmektedir.

İhtilal yüzünden yerle bir olan, unsurları yeniden şekillenen ülkeye, uzaklardan sağlayacakları kaynaklarla ideallerini filizlendirecek, bu arada sanki oralar lehine varılmış edasıyla yola çıkan Napolyon Bonaparte Fransız tüccarlarına imtiyaz ${ }^{8}$ hedefini "Mısır Mısırlılarındır" sloganyla gizleyip ülkesine hizmet ederken, tarihin en köklü unsurunun notunu da alarak ülkesine dönecekti. Gelişmeler "psikolojik harbi"9 ortaya çıkarıp şekillendirecek bilimden sanata kadar propaganday1 ${ }^{10}$ adeta bir "silaha"11 dönüştürerek etkin bir şekilde kullanılmasına sebep olacaktır.

Türkiye, Doğu Akdeniz, İslam Dünyası tek tek ya da topluca ele alındığında, birçok başlangıç belirlenebilir. Ancak söylemleriyle Mısır için gelenlerin eylemlerinin farklı güzergâhta olmasından dolayı bu olayı başlangıç saymak; yanılma payı koymak şartıyla yararlı ve isabetli olabilecek gibi görünmektedir. Bu araştırmada güncel gelişmelerin farklı unsurlarını ilgili bilim dalı mensuplarına bırakarak tarihçilik açısından değerlendirmelerde bulunmaya çalışılacaktır.

\footnotetext{
${ }^{1}$ TracyBowel, GaryKemp (2018), Eleştirel Düşünme Kılavuzu, (Trc. Bilge Tanrıseven), Tübitak Yay., Ankara Eylül 2018 , s. 1.

${ }^{2}$ Hasan Duman, Kültür Stratejileri ve Millî Kültür Politikamız (Bir Bürokratın Çırpınışları), Enformasyon ve Dokümantasyon Hizmetleri Vakfı Yay., Ankara 2008, s. 511.

${ }^{3}$ Fatma Acun, Yakın Dönem Tarihi Metodolojisi, Siyasal Kitabevi Yay., Ankara Temmuz 2017, s. 30.

${ }^{4}$ Enver Ziya Karal, Osmanl Tarihi, V, Türk Tarih Kurumu Yay., Ankara 1988, ss. 22-25.

${ }^{5}$ İlknur Türe, "Amerikan Tarihini Farklı Okumak: Kuruluş ve Anayasa Tarihine Alternatif Bir Bakış", Türkiye Günlüğü, nr. 137, Kış 2019, s. 92.

${ }^{6}$ Birol Kovancilar, Hayat Bir Pazar Yeri, Liberte Yay., Ankara Ocak 2011, 23.

${ }^{7}$ Garth S. Jowett, VictoryaO'Donnel, Propaganda andPersiasion, California 1992, p. 2.

${ }^{8}$ M. Smith Anderson, Doğu Sorunu (1774-1923), (Trc. İdil Eser), Yapı Kredi Yay., İstanbul Mart 2001, s. 42.

9 İsmail Hakkı Alpay, "Psikolojik Harp", Ordu, nr. 167, Eylül 1953, ss. 8-20; Abdullah Argun, "Psikolojik Harp", Ordu, nr. 190-191, Haziran/ Eylül 1959, ss. 72-82.

${ }_{10}$ Alpaslan Kayaltepe, "Propaganda", Ordu, nr. 173, Mart 1955, 10-15.

11 İsmail Hakkı Alpay, "Psikolojik Harbin Silahı Propaganda ve Şaiyalar Üzerinde Bir Tetkik", Ordu, nr. 169, Mart 1954, ss. 1-19.
} 


\section{T. Akkoyun}

\section{MESELELER ve REALITE}

1.1 Doğu Akdeniz ve bütün Akdeniz'in ${ }^{12}$ eski çağdan beri hemen her alanda önemi bilinmektedir. Rejimleri değişse de Rusların sıcak denizlere inme ${ }^{13}$ politikasının değişmemesi, uluslararası siyasetin gözü önünde cereyan etmiştir. Ancak hamleler, daha başka hususiyetler üzerinden gerçekleştirilerek "kutsal yerler"14 üzerinden kurgulanmıştır. Benzer projeler yürütülmeye devam edip gitmektedir.

Tarihî İpek ve Baharat yollarının üzerinde, tek tanrılı dinlerin çıkış merkezinde bulunması gibi ana sebeplerin öne çıkardığı Orta Doğu, son bir kaç yüzyıldan beri dünyanın değişen üretim ve tüketim sisteminin, enerji potansiyelini bünyesinde barındırmasıyla dikkat çekmektedir. Yer altı enerji kaynaklarının Hazar Havzasından Akdeniz Havzasına kadar uzanması, bilim ve teknolojinin siyasetin önünde seyretmesiyle bazı hamlelerin ancak uygulamadan sonra değerlendirilme zaruretini ortaya çıkarmaktadır.

1.2 Fransız Devriminin etkilerinin hissedilmesiyle tarihî süreç içerisinde Mısır Meselesi, Balkan Meselesi, Mora Meselesi, Kırım Meselesi, Kuzey Afrika Meselesi Osmanlı ülkesinin yabancı devletlerin iştahını kabartan örnekleri olarak sıralansa da Süveyş Kanalı'nın açılması, Kıbrıs Adası'nın kiralanması, Kuzey Afrika'nın koparılması, On İki Adanın işgali, Orta Doğu haritasının masa başında cetvelle çizilmesi, Filistin'e Yahudi göçü gibi hususların maddiyata dayalı gücü ele geçirme ve muhafaza etme amaçlı olduğu söylenebilir.

1.3 Gelişmelere ayak uydurmada hayli zorlanan Osmanlı Devleti, araştırma coğrafyasında yer alan Mısır'ın işgali sonrasında milletlerarası politikasında esaslı bir değişikliğe giderek "muvazene siyaseti" izlemeye başlarken, Fransa başta olmak üzere diğer batılı güçler Osmanlı ülkesinde kendi çıkarların ${ }^{15}$ sağlayacak, koruyacak, artıracak ve pekiştirecek projeler yürütmüşlerdir. Osmanlı yönetimi de devletlerarası rekabetten kendi lehine sonuçlar çıkarmaya özen göstermiştir. Bu çabası; "ikiyüzlü, medeniyet götüreceğim diye her türlü işgalci, sömürgeci hırslarını alevlendiren batının"16 karşısında ömrünü bir süreliğine uzatmışsa da sonucu değiştirmeye yetmemiştir. Bu zaman zarfında arazi ve nüfus anlamında kayıplara maruz kalmış, enerji kaynakları zengin olan toprakların tasfiyesi için yetiştirdiği evlatlarının çoğunu meydanlarda bırakacağı savaşlara dahil edilmiştir. Çanakkale, Kutü'l-Amâre, Mukaddes topraklar, Bakü seferi gibi "kahramanlık ritüeli" başarılar; tasfiyeyi durduramamıştır. Ele aldığımız mevzuların yakın tarihi buralarda karalanmıştır. Bu hususta bazı gelişmeleri teferruata girmeksizin şu şekilde sıralamak mümkündür:

- Takriben on yıllık bir çalışmadan sonra 17 Kasım 1869 tarihinde Süveyş Kanalı'nın açılması,

- 1880 'lerin sonlarında Orta Doğu Petrol rezervlerinin tespiti,

- Orta Doğu üzerinde İngiltere ve Almanya merkezli blokların Dünya Savaşında mücadelesi,

- Dünya Savaşları sonrası İngiliz ve Fransızların Orta Doğu petrollerini yönetmesi,

- Orta Doğu haritasının masa başında cetvelle çizilmesi,

\footnotetext{
12 Fahri Çeliker, "Stratejik Bölge Olarak Akdeniz", Stratejik Etütler Bülteni,nr. 71, Temmuz 1980, ss. 43-52.

${ }^{13}$ M. Cihat Akyol, "Sovyetler Birliği ve Sıcak Deniz Özlemi", Silahlı Kuvvetler Dergisi, nr. 240, Aralık 1971, ss. 26-36.

14 "Kırım Savaşının kıvılcımını tutuşturan 'kutsal yerler' sorunu oluşturmuştur. Osmanlı Devleti Kudüs ve çevresinde Ortodokslara ve Katoliklere ayrıcalıklar tanımasına rağmen, Rusya Ortodoksların koruyucusu olarak tek başına söz sahibi olmak istemiştir. Çıkarlarını düşünen İngiltere, Fransa, Piyomente- Sardinya (Bugünkü İtalya) Osmanlı Devleti'nin yanında yer aldılar." Zekeriya Kurşun vd., Tarih Metodu, 7. b., (Ed. Zekeriya Kurşun), Anadolu Üniversitesi Yay., Eskişehir Ocak 2016, s. 209.

${ }^{15}$ Hasan Şahin, "Doğu Sorunu Çerçevesinde Osmanl1-Fransız İlişkileri [Başlangıcından Paris Barışı'na (1856)]", Atatürk Üniversitesi Türkiyat Araştırmaları Enstitüsü Dergisi, nr. 40, 2009, s. 310.

${ }^{16}$ Lütfi Şehsuvaroğlu, Mehmet Âkif: Belgeleriyle Milli Şairin Portresi, 3. b., Hasret Yay., Ankara 2017, s. 358.
} 
- ABD'nin Orta Doğu enerji kaynaklarına paydaş olma çabaları,

- 14 Mayıs 1948 tarihinde İsrail'in kuruluşu,

- Otomotiv sektöründeki gelişmeler,

- 1960 yılında Organisation of Petrolleum Exploration Countries [OPEC] kuruluşu,

- 1973 Dünya Petrol Krizi,

- Sovyetlerin 1979 yılında Afganistan'ı işgali ve 10 yıl süren savaş,

- 1979 yılında İran'da Pehlevi iktidarı yerine "İslamî Devrim"in gelmesi,

- 22 Eylül 1980 - 20 Ağustos 1988 İran-Irak Savaşı,

- 2010 Arap Bahar1.

1.4 Bazı gelişmeler görmezlikten gelinse de Türkiye; Musul Meselesi, Ermeni Meselesi, Suriye Meselesi, Batı Trakya Türkleri, Azerbaycan Petrolleri ve Kıbrıs gerçeği ile yüz yüze gelmiştir. Gelişmelere kayıtsız kalamamaktadır. "Türkiye tarihsel, kültürel ve ulusal çıkarları itibariyle bu sorunların çözümünde dikkatli, hassas, dengeli ve diplomatik bir üslupla"17 hareket etmek zorundadır. Boğazlar ve Hatay meselelerinin lehte çözüme kavuşmasında kazanılmış tecrübelerin bulunduğu gözden uzak tutulmamalıdır. Aynı şekilde karşı tarafın Doğu Anadolu'da iç ayaklanmayı körükleyerek uluslararası hukuk kuralları içinde tarihî ve içtimaî gerçeğin ters yüz edilmesiyle, Musul Meselesinde kazanım sağladığı, siyasi ve maddî anlamda tarafımıza kalıcı zarar verdirdiği de dikkate alınmalıdır. Şüphesiz Genelkurmay Başkanından Başvekiline ve Reisicumhuruna kadar yeni Türk devleti yönetimi, enerji kaynakları zengin bu vatan parçası konusunda oldukça hassastı. Kazandığı tecrübeyle Boğazlar ve Hatay Meselesini ülke lehine çevirdiler.

1.5 Avrupalı devletler, güçlerini pekiştirme yolunda Yunanistan bağımsızlığını kendi kararlarına rağmen sağlamışlar, Kırım Harbi'nde ${ }^{18}$ Rusya'nın güneye inmelerini engellerken azınlık paketini Osmanlı ülkesine bırakmışlar, 3 Mart 1878 Ayastefanos Antlaşmasi'nı geçersiz kılarken antlaşma metninde yer alan etnik unsur hususiyetini 13 Temmuz 1878 Berlin Antlaşmasi'na taşımışlar, çok geçmeden araştırma konusunun merkezinde yer alan Kıbrıs Adası'nı kiralama yoluna gitmişlerdir. Osmanlı devlet idaresi de "kiralama" eyleminin ne anlama geldiğini bildiğinden devletlerarasında meydana gelen ve gelmesi muhtemel rekabet ortamından istifade ederek ağırlığından yeni bir miktar kaybetmeden "hasta" diye tanımlanan ama dikkate alınan bir güç olarak kalmaya çalışmıştır.

1.6 Tarihî hadiseleri tek çizgiden takip edebilmek mümkün olmadığından Süveyş Kanalı'nın açılması gündeme gelmesiyle Kıbrıs Adası'nın daha da önem kazandığı yönünde fikir yürütmek mümkündür. Kanalın tesisi, coğrafi keşiflerin Akdeniz'den aldığı deniz ticareti gerçeği yeniden geriye dönecek, Avrupa'nın gücünü daha az maliyetle kalıcı kılacak bir unsurdu. Kanalın kısa ve uzun vadeli güvenliği açısından Kıbrıs'tan daha uygun bir yer yoktu.

1869 yılında "Misır topraklarında bulunan, $161 \mathrm{~km}$ uzunluğunda yapay su yolu"19 Süveyş Kanalı'nın²0 açılışı, Orta Doğu Petrolleri, Hazar Petrol Havzası enerji kaynaklarının tüketim pazarlarına transferi bölgenin önemini muhafaza etmesine neden olmaktadır. 1914 yılına kadar Osmanlı egemenliğinde görülse de Britanya işgali altıda olan bu sahada projeler geliştirilmiştir. Zira Kıbrıs da 1878 yılında Britanya tarafından kiralanmıştı. -Dünya savaşının ana hedefinin

\footnotetext{
${ }^{17}$ Muhittin Demiray, "Türkiye'nin Dış Politikasında Tahteveralli Denge Politikası ve Avrupa Birliği'nin Türkiye'nin Dış Politikasına Bakışı: Ortadoğu Örneği", Değişen Ortadoğuda Kültür ve Siyaset, (Ed. Yasin Aktay vd.), Stratejik Düşünce Enstitüsü Yay., Ankara Mart 2012, s. 694.

${ }^{18}$ Kemal Gurulkan vd., Osmanlı Belgelerinde Kırım Savaşı (1853-1856), Başbakanlık Devlet Arşivleri Genel Müdürlüğü Yay., Ankara 2006; F. Rezzan Ünalp, "İlklerin Savaşı: Kırım Savaşı (1853-1856)", Askerî Tarih Araştırmaları Dergisi,nr. 22, 2013, ss. 1-17.

${ }^{19}$ Ali Yiğit, "Ortadoğu, Enerji ve Savaş", TMMOB EMO Ankara Şubesi Haber Bülteni,nr. 2, 2013, s. 10.

${ }^{20}$ Vahit Şenuyar, "Süveyş Kanalının Önemi", Silahlı Kuvvetler Dergisi, nr. 227, 1968, ss. 48-51.
} 


\section{T. Akkoyun}

anlaşılmasına katkı yapacak bir şekilde- 1914 yılında adayı ilhak etmiş, Lozan Barış Antlaşmasıyla durumu Türkiye de benimsemişti. 1983 yılında KKTC kurulsa da sadece Türkiye Cumhuriyeti tanımıştır. "Türkiye'nin yalnızlığı ve içine sürüklendiği kaos", başını kaldırmasıyla olayın boyutu daha da değişmiştir. ${ }^{21}$ Orta Doğu ve Hazar Havzasının mevcut ve yapılması planlanan transfer hatları Doğu Akdeniz'e inmiş, böylelikle burasını "bir anlamda enerji terminali" haline getirmiştir.22 Kısaca özetlenen enerji kaynaklarının zenginliği, bölgedeki iç dinamik ve zaaflar kadar, irili ufaklı devletlerarasındaki gerilimi de en üste taşımaya yetmektedir. Devletlerin ilk hedefi hiçbir şekilde bu havzadan, bu bölgeden, bu pastadan uzak kalmamak, ardından payını artırarak rakiplere karşı üstünlük elde ederek arayı açmaktır. En küçük ihmalin telafisi kolay görünmemektedir.

1.7 Petrol, doğalgaz başta olmak üzere enerji kaynaklarının sınırları zorladığı, birbirini tamamlayıcı geleneksel rollerin benimsendiği coğrafyadaki ${ }^{23}$ gelişmeler, tek tek devletleri, bölgeyi, Avrasya olarak tanımlanan eski dünyayı, yenidünyayı ve bütün geleceği doğrudan tesir edebilecek hususlardır. XX. Yüzyılın ortalarında İngiltere Başbakanı Anthony Eden "Kıbrıs, Petrol ve ülkeye geliş kaynağı" arasında bir bağlantı kurarak aksi durumda ülkesinde işsizlik ve kıtlı̆̆ın²4 kaçınılmazlığına vurgu yapmaktan çekinmemiştir. "Bir damla petrol, bir damla kan"25 ifadesi uluslararası platformlarda karşılık bulur hale gelmiştir. Teşbihte hata olmayacağından hareketle "petrole" yani enerji kaynağına "tapmalar"26 asrın problemi ${ }^{27}$ yani tam anlamıyla "ekonomik harp"28 söz ${ }^{29}$ konusudur. Diğer örneklerde olduğu gibi enerji merkezli savaşlar ve çatışmalar araştırma bölgesinde [Bosna-Hersek, Balkanlar, Filistin, Lübnan'a dair] gerçekleştirilen incelemelerde, "savaş stresine karşı çocukların psikolojik tepkilerini"30 ortaya koymaktadır. Ayrıca burada tarihin derinliklerinden bugüne ulaşan üç renkli ve zengin aktör; mevcudiyetini bir şekilde sürdürmeye devam etmektedir: Türkiye, İran ve Misır.

\section{DOĞU AKDENİZ ve ENERJi}

2.1 "Ne yazık ki, bölgedeki gelişmelere aktif olarak müdahalede bulunamayan"31 ve "enerji fakiri bir ülke olarak tamamen dışa bağımlı"32 Türkiye'nin geleceği açısından son derece önem arz eden Doğu Akdeniz; İtalya, Slovenya, Hirvatistan, Bosna-Hersek, Karadağ, Arnavutluk,

\footnotetext{
${ }^{21}$ Özer Balkaş, Doğu Akdeniz'de Doğalgaz Keşifleri, Pazarlama Senaryoları, Enerji Güvenliği ve Jeopolitika, Jeoloji Mühendisleri Odası, 14 Mart 2019, s. 34.

${ }^{22}$ Işılay Acar, Mutlu Yılmaz, "Doğu Akdeniz Kıta Sahanlığı Sorunsalı Üzerinden Doğalgaz Paylaşımı", TUCAUM $30 . Y_{\imath} l$ Coğrafya Sempozyumu 3-6 Ekim 2018, Ankara 2018, s. 599.

${ }^{23}$ Dursun Yıldız, Doğu Akdeniz'de Isınan Sular, Bizim Kitaplar Yay., İstanbul 2009, s. 19.

24 A. James, Keeping the Peace in the Cyprus Crises of 1963-64, Palgrave, Newyork 2002, p. 11.

25 Saim Besbelli, "Bir Damla Petrol, Bir Damla Kan", Ordu, nr. 165, Mart 1953, ss. 96-103; Bedrettin Demirel, "Bir Damla Kan, Bir Damla Petrol", Silahlı Kuvvetler Dergisi, nr. 236, Aralık 1970, ss. 35-37; Zeki Gonca, "Petrolün Dünya Politikasına Etkisi", Stratejik Etütler Bülteni, nr. 33, Ekim 1972, ss. 51-57; Arnold Hottinger, "İsrail Cephesi ve 'Petrol Silahi' Arasında Arap Dünyası", Stratejik Etütler Bülteni, nr. 39, Ekim 1973, ss. 54-62; Turhan Erdem, "Harbin Kanı Petrol", Silahlı Kuvvetler Dergisi, nr. 252, Aralık 1974, ss. 90-99.

${ }^{26}$ Halûk V. Saltıkgil, "Dünyada ve Türkiye'de Petrol: Ateşe Tapanlardan Petrole Tapanlara", Belgelerle Türk Tarihi Dergisi, nr. 29, Şubat 1970, ss. 43-50.

${ }^{27}$ Şükrü Bayındır, "XX. Yüzyıl Sorunu: Benzin", Silahlı Kuvvetler Dergisi, nr. 278, Haziran 1981, ss. 63-81.

28 İsmail Hakkı Alpay, "Ekonomik Harp", Ordu, nr. 170, Haziran 1954, ss. 76-95.

${ }^{29}$ Chantaux Jacques, "İran-Irak Savaşı'nın Denizlerdeki Görüntüsü ve Ortadoğu'daki Petrol Trafiğinin Geleceği", (Trc. Hüseyin Işık), Silahlı Kuvvetler Dergisi, nr. 294, Kasım 1984, ss. 58-63.

30 Zahir Kızmaz, "Çatışma, Terör ve Savaşın Çocuklar Üzerindeki Etkisi", Şiddet ve Sosyal Travmalar, III, (Ed. Adem Solak), HEGEM Yay., Ankara 2018, s. 4-5.

${ }^{31}$ Bilgehan Atsız Gökdağ, "Orta Doğu'daki Türk Varlığı", Yeni Türkiye, nr. 82, Ocak-Haziran 2016, s. 156.

${ }^{32}$ Mehmet Güneş, Tayfun Arslan, "Enerji Bağımlığında Avrupa Birliği, Rusya, Türkiye Üçgeni ve Doğu Akdeniz Alanı", International Journal of HumanitiesandEducation, IV, nr. 7, 2018, s. 46.
} 
Yunanistan, Türkiye, Suriye, Lübnan, İsrail, Filistin, Mısır, Libya, Tunus kıyılarıyla çevrilidir. ${ }^{33}$ "Bataklık" olduğu dahilî siyasette iddia edilen Orta Doğu'nun, problemleri Doğu Akdeniz'den ayrı düşünülmemelidir. Yakın geçmişe dayanan bilhassa 2009 yılından sonra "İsrail, Lübnan, Kıbrıs ve Suriye"34 gibi sahadaki doğalgaz arama, tespit, üretim, transfer faaliyetleri, coğrafyadaki önceki ve sonraki hareketlenmeler dikkat çekmektedir.

2.2 Kıbrıs; sadece Türk-Rum, Türkiye-Yunanistan arasındaki "dar kapsamlı" bir mesele değildir. 1815 Viyana Kongresi'nde benimsenen, müteakiben istikrarlı ve sistemli bir şekilde takip edilip uygulanan "Şark Meselesi" kapsamında düşünülmeli ve değerlendirilmelidir. Yani Türklüğü yok etmek, Asya bozkırlarına kadar sürmek ya da gücünü en aza indirme yönünde politikalar üretme esaslıdır. Adada yaşananlar, yaşanması muhtemel tehlikeler tarihî politika çerçevesinde bir anlam taşımaktadır. Bölgenin istikrarı havalinin menfaatine, aksi durum ise büyük güçlerin siyasi ve ekonomik çıkarlarına hizmet etmektedir. Daha fazla gelir havuzu adresinin belirlenmesi mücadelesi alabildiğince sürecek, paydaşların sayısı belirlenecektir. Bölge insanlarının bundan yararlanıp yararlanmaması ancak film şeritlerindeki değerler kadar bir anlam taşımaktadır.

Yeniden tarih istikametine bakılacak olursa, İngilizler 1878 Berlin Antlaşmasi'ndan sonra Kıbrıs'a yerleşti. Aynı antlaşmanın Balkanlar, Kafkasya, Osmanlı'nın dahilî işlerine dair hükümleri bütünleştirilerek ele alındığında milletlerarası projelerin istikameti konusunda fikir yürütmek de mümkün görünmektedir. Durumun ağırlığını hisseden genç padişah II. Abdülhamit'in de Osmanlı'ya yönelik projeleri dikkatle takip ettiği, onları geçersiz kılmaya çalıştığı, çok geçmeden toplumun kendi değerleri ile dinamiklerinden alternatif projeler ve fikirler üretip dünyayı ürküttüğü dikkatlerden kaçmamaktadır. Bu çabaların kısa vadeli çözümlerden ziyade uzun mücadeleler gerektiğini fark etmiş olmalıdır ki ülke çapında büyük eğitim hamlelerine girişmiş, toplumun her kademesinin bundan yararlanması yolunda bir sistem geliştirmiştir. ${ }^{35}$

2.3 Birinci Dünya Savaşı içinde batılı devletler filmleri aratmayan projeler üreterek, Orta Doğu'da serbest hareket etmenin yolunu açmış, yerli toplulukların kendi içlerinde ve birbirleriyle ilişkilerini kopartacak tohumları ekmiş, yüzyılın mutlak enerji havzalarında istikrarı tamamen yok etmiş, başarısını beyazperdeye ${ }^{36}$ aktararak dünyaya defalarca izletmiştir. Arabistanlı Lawrence (Yönetmen: David Lean, 1962) tarihin silik ama esaslı bir görüntüsü olarak dünya sinemasının seçkin eserlerinden birisi olarak yedi dalda Oscar kazanmıştır. Canlılığını hala koruyan bir sinema ürünü olmuştur. Bölgede meydana gelen insanlığı dahi utandıran hadiseler karşısında "miskince denilebilecek sessizlik"37 sanat eserlerinde Rambo'ya (Yönetmen: Peter Macdonald: 1988) kadar uzanan "kahramanlığa!" dönüştürülmüştür. Her şeye rağmen "direniş"38 sürmüştür.

2.4 Yine Birinci Dünya Savaşı içinde 1917 yılında İngiliz Komutan General Allenby Kudüs'e büyük bir törenle girdiğinde geleceğin hesapları yapılmasına karşın "Arslan Yürekli Richard" ile kıyaslamalar yapıldı. ${ }^{39}$ Kendi hedefleriyle geleceğe yürüyenler, aynı şekilde mevcut anı geçmişe bağlayarak kalıcı olmaya çalışmaktaydı.

\footnotetext{
${ }_{33}$ Cihat Yaycı, "Doğu Akdeniz'de Deniz Yetki Alanlarının Sınırlandırılması Sorunu ve Türkiye", Bilge Strateji, IV, nr. 6, 2002, s. 2.

${ }^{34}$ Hakîm Darbouche Oth., "East Mediterranean Gas: What Kind of a game-Changer", The Oxford Institüte for Energy Studies, NG 71, December, 2012, pp. 9-18.

${ }^{35}$ Bayram Kodaman, Abdülhamid Devri Ĕ̆itim Sistemi, Ötüken Nşr., İstanbul 1991.

${ }^{36}$ Turan Akkoyun, "Orta Doğu'da Emperyalist 'Bilgeliğin' Beyazperde Görüntüsü: Arabistanlı Lawrence", Yeni Türkiye, nr. 83, Ocak-Haziran 2016, ss. 664-675.

${ }^{37}$ Vecdi Bürün, "Afganistan Unutuldu mu?", Olaylara Bakış, 13-20 Ocak 1984, nr. 17, s. 19.

${ }^{38}$ Cemal Özkan, "Afgan Direnişi Karşısında Hür Dünya", Silahl Kuvvetler Dergisi, nr. 302, Mart 1986, ss. 30-38.

${ }^{39}$ Mücahit Türköne, "Gönüller Sultanı: Kudüs", Yerli Düşünce, nr. 25, Ocak 2017, s. 94.
} 


\section{T. Akkoyun}

2.5 Türk milleti Mondros Ateşkesi sonrasında başlattığı mahalli mukavemeti, Mustafa Kemal Paşa'nın liderliğinde Millî Mücadele'ye dönüştürüp Sovyetler Birliği, İtalya ve Fransa emperyalist emellerinin mühim bir kısmından vazgeçirilmişlerdir. Araştırma konusu itibariyle 20 Ekim 1921 Ankara İtilafnamesit0 ile Fransızlar İskenderun Sancağı hariç işgali sonlandırmışlardır. Lozan Barış Antlaşmasi'nın "Topraklara ilişkin Hükümler" içinde yer alan 16. madde şöyledir: "Türkiye işbu Andlaşma ile belirlenen sınırları dişındaki tüm topraklar ile bu topraklardan olup gene bu andlaşma ile üzerinde kendi egemenlik hakkı tanınmış bulunanlar dışındaki Adalarda - ki bu toprak ve adaların geleceği ilgililerce saptanmış ya da saptanacaktı - her ne nitelikte olursa olsun, sahip olduğu tüm hak ve senetlerden vazgeçtiğini açıklar. İşbu Maddenin hükümleri komşuluk nedeniyle Türkiye ile ortak sınırı bulunan ülkeler arasında kararlaştırılmış ya da kararlaştırılacak olan özel hükümleri bozmaz." ${ }^{41} \mathrm{Bu}$ madde ile Türkiye, "mevcut sınırların dışında hak iddia etmeyeceğini" kabul etmiştir.

Aynı antlaşmanın 20. maddesi de şöyledir: "Türkiye, Britanya Hükümetince Kıbrıs'ın 5 Kasım 1914'te açıklanan ilhakını tanıdığını bildirir."42 Bu hükümlere göre Kıbrıs hudutlarımız dışında kalmıştır. İki süper gücün rekabetindeki Akdeniz'in ${ }^{43}$ bu önemli adasında XX. yüzyılın ikinci yarısında "milletlerarası antlaşmalarla tanınmış en tabii haklarını korumak isteyen Kıbrıslı soydaşlarımız, dünyanın gözü önünde, hunharca katledildi; ihtiyarlar, kadınlar, çocuklar öldürüldü." ${ }^{44}$ Kıbrıs Barış Harekatı sonrasında adanın da içinde bulunduğu tüm Doğu Akdeniz'de "tehlikeli bir rekabete" ${ }^{45}$ girişilmiştir.

2.6 Dünyanın gündemine yerleşen Doğu Akdeniz'de kıyısı bulunan Türkiye, Yunanistan, Güney Kıbrıs Rum Kesimi, İsrail, Lübnan, Mısır karşı karşıya gelmiştir. Suriye mevcut durumuyla bu mevzuuyla ilgilenecek gücü kendinde bulamamaktadır. "Bölgede çıkarılacak doğalgazın çok az bir kısmını Kıbrıs ve İsrail tüketecektir. Tüketimden kalan kısmın nasıl taşınacağı henüz netliğe kavuşmuş değildir."46 Devletlerarası paylaşımın nereye kadar uzanabileceği üzerinde fikir yürütmek de kolay olmamaktadır. Belirli bir aşamadan sonra dünyada egemenlik kurmak isteyen bir gücün ilk basamağı ya da hedefi Akdeniz ${ }^{47}$ olması mantıklı bir iddiadır. XX. yüzyıl müddetince artarak sürüp gelen problemlere rağmen çağdaş, millî, laik ve demokratik mevcudiyetini kabul ettiren Türkiye Cumhuriyeti XXI. yüzyıl ve III. bin yıla girdiğinde bulunduğu stratejik alanda çözüm üretmesi kaçınılmaz hale gelen adeta "ateşten bir gömlek"48 tarafından ablukaya alınmıştır.

2.7 "Akdeniz ve Ege'de petrol ve doğalgaz araştırmalarında strateji ve politikaları nelerdir" 722363 numaralı Yazılı Soru Önergesine Enerji ve Tabii Kaynaklar Bakanı Taner Yıldız'ın 4 Haziran 2013 tarih ve 1685 numaralı yazılı cevabından anlaşıldığı kadarıyla; "Türkiye Petrolleri Anonim Ortaklığı (TPAO), Doğu Akdeniz olarak tanımlanan, coğrafik bölgenin onshpreloffhore alanlarındaki hidrokarbon arama çalışmaların uzun yıllardan beri sürdürmektedir. Türkiye Petrolleri özellikle 2007 yılından itibaren, Akdeniz offshoreunun hidrokarbon potansiyelini ortaya koymak ve ülke ekonomisine kazandırmak amacıyla deniz alanlarındaki (offshore) sondaj öncesi faaliyetleri artırmış ve ciddi bir yatırım yaparak 2005-2012 yılları arasında toplam $33.588 \mathrm{~km}$ 2B ve $2.582 \mathrm{~km} 23$ B sismik veri setine sahip olmuştur.

${ }^{40} H T V D$, nr. 59, Vesika 1342; İsmail Soysal, Tarihçeleri ve Açıklamaları ile Birlikte Türkiye'nin Siyasal Antlaşmaları (19201945),I, Türk Tarih Kurumu Yay., Ankara 1983, ss. 48-60.

${ }^{41}$ Soysal, a.g.e., s. 91.

${ }^{42}$ Ay. Es., ay. yer.

${ }^{43}$ Feridun Akkor, "Akdeniz ve İki Büyükler", Silahlı Kuvvetler Dergisi, nr. 259, Eylül 1976, ss. 13-19.

44 İbrahim Kafesoğlu, "Kıbrıs Faciası ve Tarih", Öğretmen, nr. 216, 25 Ocak 1967, s. 4-5, 7.

${ }^{45}$ Jacgues Menoncourt, "Doğu Akdeniz'de Tehlikeli Türk-Yunan Rekabeti", Stratejik Etütler Bülteni, nr. 57, Ekim 1976, ss. 18-29.

${ }^{46}$ Umut Kedikli, Taşkın Deniz, "Enerji Kaynakları Mücadelesinde Doğu Akdeniz Havzası ve Deniz Yetki Alanları Uyuşmazlığı", Alternatif Politika, VII, nr. 3, Ekim 2015, s. 412.

${ }^{47}$ P. Singh, "Conceptual Understanding of Geopolitics with Special Reference toIndian Ocean", IJAR, I (6), 2015, p. 283.

48 "Türkiye'nin Çevresi Ateşten Gömlek", Cumhuriyet, 17 Aralık 2000. 
... TPAO, 2011 yılı son çeyreğinde Doğu Akdeniz'de çok ciddi ruhsatlandırma çalışması sürdürmüş olup, bu kapsamda bir taraftan bölgedeki mevcut istikşaf ruhsatlarm arama ruhsatına çevirirken, diğer taraftan da batıda Girit Adası, doğuda ise Suriye offshoruna kadar uzanan alanda, uluslararası deniz hukukundan kaynaklanan hakları çerçevesinde, yeni ruhsat alanları oluşturarak bu coğrafyada yetki alanların genişletmiş̧ir. ... Diğer taraftan TPAO ile KKTC Ekonomi ve Enerji Bakanlı̆̆ı arasında 11 Kasım 2011 tarihinde KKTC'ye ait denizde 7, karada 2 olmak üzere toplam 9 ruhsatta 'Petrol Sahası Hizmetleri ve Üretim Paylaşım Sözleşmesi' imzalamıştır. Masrafların tamamı KKTC'ye ait olmak üzere, TPAO tarafından yürütülecek faaliyetlerin ana hatlarının belirlendiği bu sözleşme, 23 Kasım 2011 tarihli KKTC Resmi Gazetesi'nde yer alan Bakanlar Kurulu Kararı ile onaylanmıştır. ... TPAO Doğu Akdeniz'deki arama faaliyetlerini kendi yetkisindeki ruhsatlar ile sınırlandırmamış tıpkı KKTC ortaklı̆̆ında olduğu gibi diğer komşu ülkelerin deniz yetki alanlarındaki çalışmaların da takip ederek ihalelerine katılma yönünde bir dizi çalışma yürütmüştür. Bu strateji doğrultusunda öncelikle Lübnan offshoreunda var olan sismik data satın alınmış ve değerlendirilmiştir. Söz konusu çalışma sonrasında ise 19 Eylül 2012 tarihinde SHELL- TPAONIPPON konsorsiyumu oluşturulmuş ve Lübnan deniz ihalesine girmek için 18 Nisan 2013 tarihinde ön yeterlilik belgesi Lübnan Enerji ve Su Bakanlı̆̆ından alınmıştır." 49

2.8 Türkiye; gerek resmî, gerek yarı resmî gerekse STK vasıtasıyla zinde kalmaya özen göstermekte, çalışmalarını çeşitli vesilelerle kamuoyuna iletmeye ve ilgi uyandırmaya çalışmaktadır. Bunlardan birisi 2015 yılında Türk Dünyası Mühendisler ve Mimarlar Birliği tarafından Afyonkarahisar'da gerçekleştirilen "100 Y1l Sonra Kıta Aşan Projelerle Afyon Şehrengizi"50 etkinliğinde anavatan ile yavru vatan arasında "dünyada eşi ve benzeri bulunmayan" su götürme projesi aktarılmıştı.- "Çanakkale'den Kocatepe'ye" başlıklı bir bildiri ile iştirak ettiğimiz bu anlamlı etkinliğin yayınlanmamış olması büyük bir eksikliktir.- $\mathrm{Bu}$ ve benzer girişimler Türkiye'nin tarihine erişim çabası olup durmaksızın yenilenmeli, idealist anlamda bayrak yarışına genç kuşaklar dahil edilmelidir.

2.9 Kıbrıs'ın da dahil olduğu Doğu Akdeniz'de istikrarsızlı̆̆ın ana sebebi, sahibi olduğu enerji rezervleridir. Adanın güneyinde Amerikan Noble Enerji ile İsrail'li Delek firmalarının konsorsiyumu doğalgaz çalışmaları Güney Kıbrıs'ın 100 yıllık enerji ihtiyacını karşılayacak rezerve sahip olduğunu göstermektedir. Ayrıca Fransız, İtalyan, Kore ve Rus şirketleri de adanın doğalgazını yakından takip etmektedir. İsrail'in Tamar ve Leviathan bölgelerinde bulunan doğalgazın sahibi de Noble-Delek ortaklığıdır. Bu doğalgazın Avrupa'ya aktarılması için en uygun yol Türkiye üzerinden geçmektedir. Bilimsel verilere göre "Doğu Akdeniz'deki petrol ve doğalgaz yatakları bölgeyi stratejik bir enerji üssüne dönüştürmüştür. Uluslararası güçlerin Doğu Akdeniz'e ve enerji kaynaklarına sahip olmak istediği" aşikardır. Orta Doğu'daki ve bağlantılı olarak Doğu Akdeniz'deki kargaşanın ana nedeni "enerji kaynakları" ve muhtemel transfer yolundan dolayı "güçlü bir Türkiye istenmemesidir."51

\section{YABANCI GÜÇLERİ BUNALTAN UNSUR: TÜRKLER ve GÜÇLÜ TÜRKIYYE}

3.1 İslamiyet ile şereflenen Türklük; dahil olduğu medeniyete ve aleme siyasî, askerî, iktisadî, içtimaî ve kültürel anlamda tarihten izlenebilen büyük katkılar ${ }^{52}$ sağlamıştır. Oğuzların Anadolu'yu Türklüğün ikinci anavatanı haline dönüştürmesi esnasında kitlelerinin ekseriyeti;

\footnotetext{
${ }^{49}$ TBMM Başkanlığının 9.5.2013 tarih 43452547-120-00-122442 sayısına ilgi ile Enerji ve Tabii Kaynaklar Bakanlığ1 Strateji Geliştirme Başkanlığı'na ait cevabı.

50 "100 Y1l Sonra Kıta Aşan Projelerle Afyon Şehrengizi", 09.04.2015 www.tdmmb.org.tr erişim 27 Ağustos 201918.53

${ }^{51}$ Ergül Yaşar, "Doğu Akdeniz'de Petrol Oyunu", İskenderun Teknik Üniversitesi Haber Merkezi Bülteni, 2016, s. 1-2.

52 İsmail Hami Danişmend, Türklük Meseleleri, 2. b., İstanbul Kitabevi Yay., İstanbul 1983, s. 116.
} 


\section{T. Akkoyun}

Doğu Akdeniz'i çevreleyen araziden bilhassa Halep üzerinden gelmiştir. Böyle olunca havali; Malatya, Kayseri, Sivas, Konya, İznik, Bursa ile bütünleşmiştir. Türkiye Devleti'nin kurucusu Selçuklu hanedanından Kutalmışoğlu Süleyman Şah da Anadolu'ya buradan dahil olmuş, yine bu coğrafyada şehit olmuştur. Selçuklu seyyahlarının da ifade ettiği üzere "bolluk, bereket Şam'da, şefkat ise Anadolu'dadır." 53 Sultan Alaeddin Keykubad'ın fethettiği Alaiye "Gerçek bir ticaret şehri idi, buraya Mısır'dan, İskenderiye'den ve Suriye'den birçok tüccarlar gelirdi. Misır kereste ihtiyacını burada karşılardı." ${ }^{54}$ Osmanlı Yükselme döneminde Fatih Sultan Mehmet ömrünün son zamanları ile oğlu II. Beyazıt, Doğu Akdeniz'e inme çabaları göstermiş, ancak Yavuz Sultan Selim ordusuyla Doğu Akdeniz'i devlete dahil etmiş, Kanuni Sultan Süleyman Akdeniz'i çevrelemiş, 1571 yılında Kıbrıs Adası fethedilmiştir. "Osmanlılar yavaş yavaş Doğu Akdeniz'i fethederken bölgede ticaret koşullarını belirlediler, Avrupa'yla Akdeniz'i ve Hindistan'ı bağlayan yolları denetim altına aldılar." 55 Kısaca 1000 yıla yaklaşan bir zaman zarfında Türkler; araştırma konusu coğrafyanın esaslı ve tarihî bir unsuru olmuştur. Ayrıca Türkistan başta olmak üzere Türk Dünyasının farklı noktalarından Hac vazifesini görmek üzere yola çıkanlar önce "halifenin bulunduğu" payitaht üzerinden mukaddes topraklara karayolu ya da deniz yoluyla ${ }^{56}$ bu coğrafyadan geçip gitmişlerdir. Bahsi geçtiği üzere İskenderun ve havalisi Misak-1 Millî sınırları dahilinde bulunmasına rağmen 1921 Ankara, 1923 Lozan Antlaşmalarında anavatandan uzak kalmıştı. "Dikkate değer bir başarı"57 sağlayan yeni Türk devletinin lideri, Fransız mandasının kalkmasıyla Suriye Devleti'nin kuruluş aşamasında "gerçek sahibi öz Türk olan Antakya ve İskenderun ile yöresinin mukadderatını"58 sahipsiz bırakmamış, sağlık problemlerine rağmen "gelişmeleri büyük bir titizlikle ve dikkatle takip"59 ederek, sonucu göremese de başarının zeminini hazırlamıştır. Atatürk'ün ölümünden sonra da barışçı, demokratik bir zeminden ilerleyen Türkiye, "rol model"60 olmaya ve gösterilmeye devam etmiştir. Büyük güçler de tarihî birikim sahibi bu rol modeli, coğrafi yakınlıkla zıt orantılı bir şekilde hariçte tutmayı başarmışlardır. II. Dünya Savaşının bütün şiddetiyle sürdüğ̈̈ tarihlerde Türkiye-Fransa arasında "Suriye ve Lübnan için Dostluk ve İyi Komşuluk Sözleşmesi" 30 Mart 1940 tarihinde imzalanmışsa da Mayıs 1940'da Hitler Almanyası Fransa'yı işgal edince onaylanamadı. Ancak Suriye'deki Fransız makamları ile Türkiye makamları sözleşmeyi uyguladılar. Fransız ve İngilizlerin çekilmesiyle bağımsızlığını ilan eden Suriye 8 Mart 1946 tarihinde Türkiye tarafından tanındı. "Suriye Hükümetleri Hatay'ın Türkiye'ye katılması sonucu yeni sınırı tanımak anlamına gelebilecek herhangi temel bağıtı yapmak istemediler."61 Konu sıcak tutuldu. Toplumsal dram örnekleri Propaganda (Yönetmen: Sinan Çetin, 1999) örneğinde olduğu gibi beyazperdeye yansitıldı.

3.2 Yunanistan'ın Kıbrıs ile olan tarihi bağlantısı son derece zayıftır. Mondros Ateşkes Antlaşması sonrası batılı güçler arasındaki rekabette tercih edilen kendi aralarındaki daha zayıf bir devlet olarak, Türkiye'ye karşı gönderildiği "Anadolu Macerası" sonunda, Mustafa Kemal Paşa'nın

\footnotetext{
${ }^{53}$ İbn Batuta Seyahatnamesinden Seçmeler, (Haz. İsmet Parmaksızoğlu), Millî Eğitim Basımevi, Ankara 1971, s. 3-4.

${ }^{54}$ W. Heyd, Yakın Doğu Ticaret Tarihi, (Trc. Enver Ziya Karal), Türk Tarih Kurumu Yay., Ankara 1975, s. 611.

55 Norman Davies, Avrupa Tarihi: Doğu'dan Batıya, Buz Çă̆ından Soğuk Savaşa, Urallar'dan Cebelitarık'a, Avrupa'nın Panoraması, (Trc. Ed. Mehmet Ali Kılıçbay), İmge Kitabevi Yay., Ankara 1993, s. 470.

${ }^{56}$ Orhan Kavuncu, "Türkiye'deki Türkistanlılar", Türk Yurdu, nr. 308, Nisan 2013, s. 81.

57 Donald Everet Webster, The Turkey of Atatürk: Social Process in the Turkish Reformation, The American Academy of Politicaland Social Science, Philadelphia 1939, p. 5.

${ }^{58}$ Atatürk'ün Söylev ve Demeçleri, I, (Haz. Nimet Arsan), Ankara 1997, s. 410.

59 S. Esin Dayı, "Hatay Devleti ve Hatay'ın Anavatan'a Katılması", Atatürk Üniversitesi Türkiyat Araştırmaları Enstitüsü Dergisi, nr. 19, 2002, s. 335.

${ }^{60}$ M. B. Altınışık, "The Turkish Model and Democratization in the Middle East",Arab Studies Quarterly, XXVII/1-2, 2005, pp. 45-63.

${ }^{61}$ Soysal, a.g.e.,s. 610.
} 
liderliğindeki Millî Mücadele'nin askerî zaferi Büyük Taarruz ${ }^{62}$ ile Adalar Denizi'ne tarihî ifadeyle "Akdeniz'e" dökülmüşler ancak "Avrupa'nın şımarık çocuğu" sıfatından hiçbir zaman uzaklaşmamış, Doğu Akdeniz'e daha ilerisine kadar uzanan Türkiye karşıtı legal ve illegal hareketlerde yerini her zaman muhafaza etmiştir. Çağdaş "politik, sosyal ve ekonomik sorunları doğuran nedenlerin daha önceki yılların derinliklerinde yattığından şüphe edilemez."63

3.3 Kıbrıs Adası'nın Türk tarihi, ayrı bir araştırmanın konusudur. Bölgenin demografik yapısıyla sistematik bir şekilde oynanması ile tam hedefe varılamayınca, dünyanın başka coğrafyalarında uygulanan tedhiş hareketleri, darbeler adanın Türk ahalisini tamamen yok etmeye yönelince başlangıçta; "Kıbrıs diye bir meselemiz yoktur" diyenlere rağmen bilhassa basının millî görevini yerine getirmesiyle adayla ilgilenilmek zorunda kalınmış, İsmet İnönü ve Süleyman Demirel iktidarlarında zaman zaman müdahale gündeme gelmiş ancak bu görev Bülent Ecevit ile Necmettin Erbakan koalisyonuna düşmüştür. Askerî teferruatı araştırmamızın dışında tutulan Kıbrıs Barış Harekatı ${ }^{64}$, Türk Ordusunun Misak-1 Milli sınırları haricine ilk defa kendi adına gerçekleştirmiş olduğu hassasiyeti ${ }^{5}$ büyük bir harekat olarak tarihteki yerini almıştır. "Beşparmak dağları, Mehmetçik aştı ağları" kamuoyunda o günlerden kalan bir kahramanlık ifadesi olarak toplumun harekatı benimsediğini göstermiştir. Ancak askerî zafer, diplomatik başarıyı getiremediğinden Türkiye'nin yakın geçmişteki uluslararası sorunlarından birisi olarak masasında sürekli hazır bulduğu mevzulardan olmuştur. Masadan kaldırılması yönünde siyasi iktidarı zor durumda bırakan girişimler de çözüme katkı sağlayamamıştır.

3.4 Kıbrıs, Doğu Akdeniz'de stratejik öneme haiz bir ada olarak çağlardan beri egemen güçlerin hayallerini süslemiştir. Burada yaşayan insanlar bilhassa batılı güçler tarafından kendi projelerine yaptıkları katkı kadar bir değer taşımaktadır. Türkiye ağır ambargolara göğüs gererek adanın Türk unsurunun yanında yer almakta tereddüt etmemiştir. İsrail'in, ABD'nin, İngiltere'nin, Rusya'nın, Fransa'nın, Mısır'ın bir şekilde aktif hareket kabiliyeti elde ettiği Doğu Akdeniz'de uluslararası hukuk kurallarının elverdiği ölçüde ancak tarihî sosyoloji bağlamında zinde, atik, başarılı bölge insanının umudu; güçlü Türkiye'nin var olması kaçınılmazdır. XX. yüzyıl Türklügün ekseriyetini başka diyarlarda mahzun, demir perde gerisinde esir, emperyalizm karşısında yapayalnız bırakmışsa da her zaman içerisinden yetiştirdiği evlatlarıyla yarınlara uzanmış, Mustafa Kemal Atatürk'ün liderliğinde kurduğu Türkiye Cumhuriyeti; Türk, İslam ve bütün mazlumların koru halinde küllerinden doğuşa yönelmiştir. Bu bağlamda Kıbrıs ve dahilinde bulunduğu Doğu Akdeniz özelde Türkiye'nin tarihine erişim teşebbüsü ve imtihanıdır. "Geleneğin direnişi"66 ile yeniden hayat bulmasında buna çok ihtiyaç bulunmaktadır.

3.5 "Türk tarafı her tür uluslararası toplantıda ABD, İngiltere ve diğer dost ülkelere, adada makul çözüm bulunması"67 yaklaşımında ise de "petrol ve enerji krizlerinin yaşandığı 70'lerin ardından sürekli olarak bölgesel çatışmalar var olmuş, bunların bazılarına 'Süper Güç' olarak nitelendirilen ülkeler de taraf olmuşlardır."68 Egemen güçlerin ürettiği siyasetler etkili olmuştur.

\footnotetext{
62 Songül Keçili, “Tarihçilik Açısından Büyük Taarruz Sahasının Ekoturizm ile İlişkilendirilmesi”, Karabük Üniversitesi Sosyal Bilimler Enstitüsü Dergisi, VIII, nr. 1, 2018, ss. 116-128.

${ }^{63}$ Hayri Mutluçağ, "İngiltere'nin Ortadoğu ve Türkiye Hakkında Gizli Emelleri", Belgelerle Türk Tarihi Dergisi, nr. 26, Kasım 1969, s. 51.

${ }^{64}$ Önder Turan, Kıbrıs'ta Ak Günlere, 2. b., Milliyetçi Yay., İstanbul 1974.

${ }^{65}$ Osman Ancın, "Niçin Kıbrıs'tayız?", Silahlı Kuvvetler Dergisi, nr. 267, Eylül 1978, s. 37-38.

${ }^{66}$ Beşir Ayvazoğlu, Geleneğin Direnişi, Ötüken Nşr., İstanbul 1996, s. 9.

${ }^{67}$ Hasan Tahsin Fendoğlu, "Türk Dış Politikasında Kıbrıs", Uluslararası Boyutlarılla Kıbrıs Meselesi ve Geleceği Uluslararası Sempozyumu 11-13 Aralı 2014 Gazimağusa: Bildiriler, (Haz. Duygu Türker Çelik), ATAM Yay., Ankara 2016, s. 99.

${ }^{68}$ Selçuk Balı, Ahmet Büyükşalvarc1, 1630'dan 2010'a Finansal Krizler Tarihi: Balonlar, Panikler, Buhranlar ve Küresel Finansal Kriz,(Ed. Aslan Eyi), Çatı Kitapları Yay., İstanbul Temmuz 2011, s. 211.
} 


\section{T. Akkoyun}

3.6 Kıbrıs'ın Türklüğü hususundaki mücadelesinin yanında, 1975 yılında kurulan KTFD devlet ve meclis başkanı, 1983 tarihinde kurulan KKTC'nin 2005 yılına kadar toplamda 22 yıllık Cumhurbaşkanı Rauf Denktaş, meselenin halli yolunda birçok kez masaya oturmuştur. 2004 yılında Birleşmiş Milletler Genel Sekreteri Kofi Annan'ın hazırlamış olduğu Annan Plani'na karşı çıkışıyla yalnızlaştırıldığı görülmüştür. Adanın Türk sakinleri planı kabullendiği halde Rumlar benimsemediğinden hayata geçirilememiştir. Kıbrıs meselesi çözülemeden günümüze kadar gelmiştir. Tekrarlamak gerekirse ada meselesi bağımsız bir konu değildir. Geçmişi takip edilebilen geleceği de güç dengelerine göre şekillenmesi kaçınılmaz Şark Meselesi ile doğrudan alakalıdır. Fedakâr bir devlet adamını siyaseten yalnızlaştıran ${ }^{69}$ ama o nispette de kahramanlaştıran Şark Meselesinin karşısında durabilmiş olmasıdır. An itibariyle Kıbrıs, Doğu Akdeniz konularının çözümü enerji savaşında krizi ülke menfaatine yönetecek, kitleleri ikna edecek ve kazanımlarını dünyaya kabul ettirme hususunda başarıya ulaşacak kahramanların yalnızlığında gizli gibi durmaktadir.

3.7 ABD'nin, İngiltere'nin, Türkiye'nin sıçrama alanlarının olması kaçınılmazdır. Bunları dar bir bölgeye sıkıştırmak hayli zordur. Doğu Akdeniz'deki enerji kaynaklarının tespiti, sahiplenilmesi, pazarlanması, transferi aşamalarının sancıları eksilmeyecektir. Yakın dönemde yaşananlar bunlardan sadece bir kısmıdır. Büyük resmi yakalamaya çalışmak, büyük resimde en büyük yeri hak etmek, başkalarının görmezlikten gelmesini engelleyecek yegâne yöntemdir. Bunca plan ve projeye rağmen beş bin yıldır fark edilebilen, iki bin yıldan daha fazla bağımsız kalabilen, bin yıla aşkın bir zamandan dahil olduğu medeniyetin öncüsü, bin yıldır yeni medeniyet halkasının siyasi lideri, bin yıla yaklaşan bir zamandır ikinci anavatanına Türklerin yurdu dedirten, 200 yılı biraz aşan zamandır anayasal zeminde ilerleyerek, yüz elli yıla yakın parlamentoyla, yüzyıldır milli egemenlikle yürüyen Türk milleti; tarihine mutlaka erişim sağlayacaktır. Doğu Akdeniz'deki mevcut mücadele, onun bir halkası Kıbris meselesi; bunun ancak habercisi olabilir.

3.8 Orta Doğu, Doğu Akdeniz ya da projelerin eriştiği sonuç her şeyi açıklamaya yetmektedir. Birinci Dünya Savaşı sonrasında "suni reçeteler ve emrivakilerle gelinen nokta ortadadır. Cetvelle çizilen hudutlar tutmamıştır ve yine benzer çözümler fayda vermeyecektir."70

Hadisenin siyasi ve iktisadî cihetinden belki de çok daha önemlisi; bilimsel temelli bir güzergahının olması gerekliliğidir. Farklı bölgeleri kapsasa dahi Kıbrıs ile Doğu Akdeniz'i derinlemesine ele alan ve durmadan kendisini güncelleme yeteneği kazanmış düşünce masaları, strateji geliştirme merkezleri, uygulama ve araştırma merkezleri, enstitüler gibi kurumlar vasıtasıyla Türkiye; çalışma alanlarına sınır koymadan inceleme yaparak akademik platformlarda ilgili kurum ve şahsiyetlerle paylaşmalıdır. Çoğunlukla tercih edilen "atı alan Üsküdar'ı geçtikten sonra" gerçekleştirilen etkinliklerde bazı işlevini yitirmiş unsurlar, günü kurtarsa bile yakın geleceğe dahi katkı yapmamaktadır. Kıbrıs ile Doğu Akdeniz ya birlikte ya da birbirinden bağımsız, sosyal bilimlerle fen bilimleri çerçevesinde araştırma - geliştirme havuzları oluşturulmalıdır. Türkiye ve KKTC'den bazı üniversitelerin bu hususta ihtisaslaşması, bununla bağlantılı olarak da teknik, toplumsal ve siyasal projeler üretmeleri; çeşitli beyinler ile çantalarda bulunması muhtemel fikirlerin müzakeresine kolaylık sağlayarak konunun küllenmesini engelleyecek, bahsi geçen hususların birleştirilebilmesi halinde tahmin edilenden çok daha büyük hedeflere ulaşılmasını mümkün kılabilecektir. Tarihî açıdan bakıldığında dünyanın seyrini değiştiren yakın ve uzak olayların önceden tahmininin mümkün olmadığı aşikarken, her türlü tekamülde iki husus sürekli gündemdedir: Bilim ile Özgür Düşünce.

${ }^{69}$ Nezire Gürkan, Zirvedeki Yalnızlık Kulesi: Rauf Raif Denktaş, Cümbez Yay.,Gazimagosa 2005.

${ }^{70}$ Ali Bademci, Suriye'de Türkmenler ve Bayır-Bucak, 2. b., Ötüken Nşr. Şubat 2016, s. 246. 
3.9 Kıbrıs ve Doğu Akdeniz özelinde ancak genelde ilerleme, büyüme, dünya liderliği; işaret edilen bilimsel ve özgür düşüncenin haricinde gerçekleşemez. Defalarca dünya egemenliğini tesis eden, bunu bir "mefkûre" haline dönüştüren Türklügün kullanmadığı ama mevcudu iyi bilinen birikimi; bölgede, uluslararası platformda ve dünyada alabildiğince serbest hareket eden güçleri bunaltmaya yetmektedir.

"Tek başınaymış gibi" hareket etmenin imkansızlığı ortada, mevcut gruplarda paylar zaten paylaşılmış durumda, gelişmiş ülkelerin açık ara önde seyrettikleri sabit, iç ve dış unsurlar faaliyetleri zorlaştırıyor, uluslararası hukuk kuralları belirlenmiş iken gibi sıralanabilecek çok da mantıklı gelebilecek mazeretlere sığınmadan, egemen güçlerin de projelerine omuz vermeden kültürel, bölgesel birliktelik ve zenginliklerin yeniden şekillendirilmesi yolunun da denenmesi pragmatik olabilecektir. "Türkiye doğusundan ve kuzeyinden gelen enerji hattına Doğu Akdeniz'deki doğalgaz akışını da etkilediği anda bu Türkiye'nin doğalgaz geçişinde merkez ülke anlamı taşımaktadır. Dolayısıyla Türkiye, Doğu Akdeniz gazı ile hem alternatif oluşturma bağlamında, hem de bu gazın Avrupa'ya iletilmesinde etkin rol oynayarak enerjide bölgesel merkez üssü olma profilini giderek güçlendirecektir."71 Unutulmaması gereken "Türkiye'siz bir dünya düşünülemez. Doğu Akdeniz güvenli olmadığı vakitte de dünyanın güvenliği söz konusu olamaz."72

3.10 3-6 Ekim 2016 tarihinde Yeni Türkiye Stratejik Araştırma Merkezi tarafından gerçekleştirilen ve açllışı Cumhurbaşkanı Recep Tayyip Erdoğan tarafından yapılan Uluslararası Bilim ve Teknoloji Konferansi'nın "Kapanış Bildirgesi"nde kamuoyuyla paylaşıldığı üzere;

"XXI. yüzyılın en önemli meselesi, bilimsel, teknolojik gelişmeler ve inovasyonlardır. Bilimsel çalışmalar ve araştırmalar ancak teknolojik gelişmelere ve inovasyona dönük olursa bir anlam kazanır. Geçtiğimiz yüzyıldaki 'teknoloji transferi' algısı artık yerini teknoloji üretimine bırakmıştır. Teknoloji üretimi de ancak inovasyonlarla mümkündür. Türkiye'nin ve dünyadaki bütün ülkelerin refah ve büyümesi, topyekun başlatılacak bir inovasyon hamlesiyle gerçekleşebilecektir. Teknoloji transferi gelişmiş ülkeler ile gelişmekte olan ülkeler arasindaki açı̆̆ı kapatmak, özellikle AR-Ge harcamalarmdan tasarruf etmek için gerekli görülse de teknoloji üretimi ve inovasyonları geciktirmemesi bakımından daha dikkatli şekilde değerlendirilmelidir. Aslolan teknoloji üretimi ve inovasyondur. Tüm ülkelerin inovasyona yönelmesi halinde dünyanın refah seviyesi hızla yükselecek ve cesur yenidünyada barış ve huzur tesis edilebilecektir." Aynı Kapanış Bildirgesi'nde Türkiye için yapılan tespitler ve tavsiye kararlarında şunlar da yer almıştır: "Bilim ve teknoloji boşlukta değildir. Daima insanların üretimde ve hayatlarında karşılaştıkları sorunları çözmek için vardır. Teknoloji transferi gerekli görülse de bütün kamu kurumlarında ve özel sektörde 'teknoloji üretimi'ni ve inovasyon seferberliğini gerçekleştirebilecek bir yapı oluşturulmalıdır. Ĕ̆itim ve öğretimin ilk kademelerinden son kademesine kadar inovasyonu teşvik edecek bir sistem geliştirilmelidir. ... Türkiye için kısa, orta ve uzun vadeli AR-GE, teknoloji ve inovasyon strateji tespit edilmeli; bu çerçevede hazırlanacak programlar ve projeler süratle uygulamaya geçirilmelidir..."73

3.11 Hadiselerin gelişimine göre strateji üretmek kaçınılmaz olsa dahi bir müddet sonra ana stratejilerin duruma hakim olması yüzünden ekseriyetle sonucu değiştirme yolunda geç kalınmakta, başkalarının kazanımları üzerinde yapılan değerlendirmeler "başka bahara kalmanın" türkülerini söyletmektedir.

\footnotetext{
${ }^{71}$ Halit Hür, "Stratejik Kavşak Noktası Olan Doğu Akdeniz'de Yürütülen Enerji Politikaları ve Türkiye", International Social Sciences Studies Journal, V, (30), February 2019, p. 661.

72 Metin Sakınç, "Türkiye'nin Ulusal Güvenlik Stratejisi ve Doğu Akdeniz", Yerli Düşünce, nr. 58, Ekim 2019, s. 29.

73"Uluslararası Bilim ve Teknoloji Konferansı Kapanış Bildirgesi", Yeni Türkiye Stratejik Araştırma Merkezi, 3-6 Ekim 2016, s. 1-2.
} 


\section{SONUÇ}

Ülkeler arasında amansız bir rekabet ve yarış; gelişmişlik düzeylerini gösterdiği nispette, ülkelerin yakın ve uzak gelecekte dünyadaki konumunu belirleyecek derecede bir hayatiyet taşımaktadır. Teknolojinin gelişimini sürdürmesi üzerine geliştirilen stratejiler; halen olayların dahilinde yer alan tarihçilerin değerlendirme yapmasını zorlaştırmakta, değerlendirme yapmaktan da geri durmasına sebebiyet vermektedir. Ender araştırmalarda da diğer bilim dallarının sonuçlarından yararlanmak kaçınılmaz olmaktadır.

Antik devirlerden beri hemen her alanda tartışlmaz bir önem arz eden Doğu Akdeniz meselesinin sıcak denizlere inme politikasından asla vazgeçmeyen Ruslarla, XX. yüzyılda büyük devletlerin Orta Doğu'da ürettiği projelerle ortaya çıkan İsrail'le, bölge ülkeleriyle, Okyanus ötesindeki yenidünya lideriyle doğrudan ilgili olmasının ana sebebi; dünyanın değişen üretim ve tüketim sisteminin enerji potansiyelini bünyesinde barındırmasıdır.

Yer altı enerji kaynaklarının Hazar Havzasından Akdeniz Havzasına kadar uzanması; bilim ve teknolojinin siyasetin önünde seyretmesi yüzünden bazı hamlelerin ancak uygulamadan sonra değerlendirilme zaruretini ortaya çıkarmaktadır.

Fransız Devriminin etkilerinin hissedilmesiyle tarihî süreç içerisinde Mısır Meselesi, Balkan Meselesi, Mora Meselesi, Kırım Meselesi, Kuzey Afrika Meselesi; Osmanlı ülkesinin yabancı devletlerin iştahını kabartan örnekleri olarak sıralansa da Süveyş Kanalı'nın açılması, Kıbrıs Adası'nın kiralanması, Kuzey Afrika'nın koparılması, On İki Adanın işgali, Orta Doğu haritasının masa başında cetvelle çizilmesi, Filistin'e Yahudi göçü gibi hususların; maddiyata dayalı gücü ele geçirme ve muhafaza etme amaçlı olduğu söylenebilir. Musul Meselesi, Ermeni Meselesi, Suriye Meselesi, Batı Trakya Türkleri, Azerbaycan Petrolleri ve Kıbrıs gerçeği ile yüz yüze gelen Türkiye; hariçten yürütülen projeler yüzünden de gelişmelere kayıtsız kalamamaktadır.

Avrupalı devletler, Kırım Harbi'nde Rusya'nın güneye inmelerini engellerken "azınlık" paketini Osmanlı ülkesine bırakmışlar, Ayastefanos Antlaşması'nı geçersiz kılarken antlaşma metninde yer alan etnik unsur hususiyetini 1878 Berlin Antlaşmasi'na taşımışlar, çok geçmeden araştırma konusunun merkezinde yer alan Kıbrıs Adası'nı kiralama yoluna gitmişlerdir.

Tarihî hadiseleri tek çizgiden takip edebilmek mümkün olamadığından Süveyş Kanalı'nın gündeme gelmesiyle birlikte Kıbrıs Adası'nın daha da önem kazandı̆̆ı yönünde fikir yürütmek de mümkündür. Kanalın tesisi; coğrafi keşiflerin Akdeniz'den aldığı deniz ticareti gerçeğini yeniden geriye döndürecek bir unsurdur. Kanalın kısa ve uzun vadeli güvenliği için Kıbrıs'tan daha stratejik bir yer bulmak imkansızdır.

Petrol, doğalgaz başta olmak üzere enerji kaynaklarının sınırları zorladığı, birbirini tamamlayıcı geleneksel rollerin benimsendiği coğrafyadaki gelişmeler; tek tek devletleri, bölgeyi, Avrasya olarak tanımlanan eski dünyayı, yenidünyayı ve bütün geleceği doğrudan tesir edebilecek hususlardir.

Türkiye'nin geleceği açısından son derece önem arz eden Doğu Akdeniz; İtalya, Slovenya, Hırvatistan, Bosna-Hersek, Karadağ, Arnavutluk, Yunanistan, Türkiye, Suriye, Lübnan, İsrail, Filistin, Mısır, Libya, Tunus kıyılarıyla çevrilidir. Yakın geçmişe dayanan bilhassa 2009 yılından sonra "İsrail, Lübnan, Kıbrıs ve Suriye" gibi sahalarda; doğalgaz arama, tespit, üretim ve transfer faaliyetleri ile bahsi geçen coğrafyada gerek önceki gerekse sonraki hareketlenmeler dikkat çekmektedir.

Dünyanın gündemine yerleşen Doğu Akdeniz'de kıyısı bulunan Türkiye, Yunanistan, Güney Kıbrıs Rum Kesimi, İsrail, Lübnan ve Mısır karşı karşıya gelmiştir. Suriye mevcut durumuyla bu mevzuuyla ilgilenecek gücü kendinde bulamamaktadır. Ülkelerin sadece isimlerini ve yakın 
geçmişte yaşadıklarını araştırma konusuna bağlamak; bilimsel olarak mümkün görünmektedir. Zira "bölgede çıkarılacak doğalgazın çok az bir kısmını Kıbrıs ve İsrail tüketecektir. Tüketimden kalan kısmın nasıl taşınacağı henüz netliğe kavuşmuş değildir." Devletlerarasında paylaşımın nereye kadar uzanabileceği üzerinde fikir yürütmek de kolay olmamaktadır. Belirli bir aşamadan sonra dünyada egemenlik kurmak isteyen bir gücün ilk basamağının ya da hedefinin Akdeniz olması da oldukça mantıklı bir iddiadır.

Kıbrıs'ın da dahil olduğu Doğu Akdeniz'de istikrarsızlığın ana sebebi, sahibi olduğu enerji rezervleridir. Bilimsel verilere göre "Doğu Akdeniz'deki petrol ve doğalgaz yatakları bölgeyi stratejik bir enerji üssüne dönüştürmüştür. Uluslararası güçlerin Doğu Akdeniz'e ve enerji kaynaklarına sahip olmak istediği" aşikardır.

Oğuzların Anadolu'yu Türklüğün ikinci anavatanı haline dönüştürmesi esnasında kitlelerinin ekseriyeti Doğu Akdeniz'i çevreleyen araziden bilhassa Halep üzerinden gelmiştir. Sultan Alaeddin Keykubad'in fethettiği Alaiye "gerçek bir ticaret şehri idi, buraya Mısır'dan, İskenderiye'den ve Suriye'den birçok tüccarlar gelirdi. Mısır kereste ihtiyacını burada karşılardı." Osmanlı yükselme döneminde ömrünün son zamanlarında Fatih Sultan Mehmet ile oğlu II. Beyazıt, Doğu Akdeniz'e inme çabaları göstermiş, ancak Yavuz Sultan Selim ordusuyla Doğu Akdeniz'i devletine dahil etmiş, Kanuni Sultan Süleyman Akdeniz'i çevrelemiş, 1571 yılında Kıbrıs Adası fethedilmiştir.

İsrail'in, ABD'nin, İngiltere'nin, Rusya'nın, Fransa'nın, Mısır'ın bir şekilde aktif hareket kabiliyeti elde ettiği Doğu Akdeniz'de uluslararası hukuk kurallarının elverdiği ölçüde, ancak tarihî sosyoloji bağlamında zinde, atik ve başarılı bölge insanlarının umudu; güçlü bir Türkiye'nin var olmasıdır. Kıbrıs Adası'nın kopuşundan itibaren gelişen hadiseler esnasında Türkiye'den zaman zaman adaya bir takım müdahaleler gündeme gelmişse de bu görev Bülent Ecevit ile Necmettin Erbakan koalisyonu tarafından üstlenilmiştir. Kıbrıs Barış Harekatı, Türk Ordusunun Misak-1 Milli sınırları haricine, ilk defa kendi adına gerçekleştirmiş olduğu hassasiyeti yüksek bir harekat olarak tarihteki yerini almıştır. Türkiye ağır ambargolara göğüs gererek adanın Türk unsurunun yanında yer almakta tereddüt etmemiştir. Dolayısıyla Kıbrıs Harekatı ve sonrasında Türkiye'nin yakın dönemdeki Doğu Akdeniz politikasının; olumlu ve başarılı bir performans ortaya koymuştur.

Farklı bölgeleri kapsasa dahi Kıbrıs ile Doğu Akdeniz'i derinlemesine ele alan ve durmadan kendisini güncelleme yeteneği kazanmış düşünce masaları, strateji geliştirme merkezleri, uygulama ve araştırma merkezleri, enstitüler gibi kurumlar vasıtasıyla Türkiye; çalışma alanlarına sınır koymadan inceleme yaparak akademik platformlarda ilgili kurum ve şahsiyetlerle paylaşmalıdır. Kıbrıs ile Doğu Akdeniz ya birlikte ya da birbirinden bağımsız olarak; sosyal bilimlerle fen bilimleri çerçevesinde araştırma-geliştirme havuzları oluşturmalıdır. Türkiye ve KKTC'den bazı üniversitelerin bu hususta ihtisaslaşması ve birlikte teknik, toplumsal ve siyasal projeler üretmeleri; bahsi geçen konuyla ilişkili güncel gelişmelerin kaçırılmasını engelleyecektir.

\section{KAYNAKÇA}

\section{Belge}

TBMM Başkanlı̆̆ının 9.5.2013 tarih 43452547-120-00-122442 sayısına ilgi ile Enerji ve Tabii Kaynaklar Bakanlı̆̆ Strateji Geliştirme Başkanlı̆̆ı'na ait cevabl.

\section{Filmler}

Arabistanlı Lawrence (Yönetmen: David Lean, 1962).

Propaganda (Yönetmen: Sinan Çetin, 1999).

Rambo (Yönetmen: Peter Macdonald: 1988). 


\section{T. Akkoyun}

\section{Süreli Yayınlar ve Web Sayfaları}

Alternatif Politika

Arab Studies Quarterly

Atatürk Üniversitesi Türkiyat Araştırmaları Enstitüsü Dergisi

Belgelerle Türk Tarihi Dergisi

Bilge Strateji

Cumhuriyet

IJAR

International Journal of Humanities and Education

International Social Sciences Studies Journal

Karabük Üniversitesi Sosyal Bilimler Enstitüsü Dergisi

Olaylara Bakış

Ordu

Öğretmen

Silahlı Kuvvetler Dergisi

Stratejik Etütler Bülteni

The Oxford Institüte for Energy Studies

TMMOB EMO Ankara Şubesi Haber Bülteni

Türk Yurdu

Türkiye Günlüğü

www.tdmmb.org.tr

Yeni Türkiye

Yerli Düşünce

\section{Kitaplar, Makaleler, Bildiriler}

Acar, Işılay, Yılmaz, Mutlu, "Doğu Akdeniz Kıta Sahanlığı Sorunsalı Üzerinden Doğalgaz Paylaşımı", TUCAUM 30. Yıl Coğrafya Sempozyumu 3-6 Ekim 2018, Ankara 2018, ss. 597-607.

Acun, Fatma, Yakın Dönem Tarihi Metodolojisi, Siyasal Kitabevi Yay., Ankara Temmuz 2017.

Akkor, Feridun, "Akdeniz ve İki Büyükler", Silahlı Kuvvetler Dergisi, nr. 259, Eylül 1976, ss. 13-19.

Akkoyun, Turan, "Orta Doğu'da Emperyalist 'Bilgeliğin' Beyazperde Görüntüsü: Arabistanlı Lawrence", Yeni Türkiye, nr. 83, Ocak-Haziran 2016, ss. 664-675.

Akyol, M. Cihat, "Sovyetler Birliği ve Sıcak Deniz Özlemi", Silahlı Kuvvetler Dergisi, nr. 240, Aralık 1971, ss. $26-36$.

Alpay, İsmail Hakk1, "Psikolojik Harp", Ordu, nr. 167, Eylül 1953, ss. 8-20.

Alpay, İsmail Hakkı, "Psikolojik Harbin Silahı Propaganda ve Şaiyalar Üzerinde Bir Tetkik", Ordu, nr. 169, Mart 1954, ss. 1-19.

Alpay, İsmail Hakk1, "Ekonomik Harp", Ordu, nr. 170, Haziran 1954, ss. 76-95.

Altınışık, M. B., "The Turkish Model and Democratization in the Middle East", Arab Studies Quarterly, XXVII/1-2, 2005, pp. 45-63.

Ancın, Osman, "Niçin Kıbrıs'tayız?", Silahlı Kuvvetler Dergisi, nr. 267, Eylül 1978, s. 37-38.

Anderson, M. Smith, Doğu Sorunu (1774-1923), (Trc. İdil Eser), Yapı Kredi Yay., İstanbul Mart 2001.

Argun, Abdullah, "Psikolojik Harp", Ordu, nr. 190-191, Haziran/ Eylül 1959, ss. 72-82.

Argun, Abdullah, Atatürk'ün Söylev ve Demeçleri, I, (Haz. Nimet Arsan), Ankara 1997.

Ayvazoğlu, Beşir, Geleneğin Direnişi, Ötüken Nşr., İstanbul 1996.

Bademci, Ali, Suriye'de Türkmenler ve Bayır-Bucak, 2. b., Ötüken Nşr. Şubat 2016. 


\section{Türkiye'nin Günümüz Doğu Akdeniz Politikaları}

Balı, Selçuk, Büyükşalvarcı Ahmet, 1630'dan 2010'a Finansal Krizler Tarihi: Balonlar, Panikler, Buhranlar ve Küresel Finansal Kriz, (Ed. Aslan Eyi), Çatı Kitapları Yay., İstanbul Temmuz 2011.

Balkaş, Özer, Doğu Akdeniz'de Doğalgaz Keşifleri, Pazarlama Senaryolarl, Enerji Güvenliği ve Jeopolitika, Jeoloji Mühendisleri Odas1, 14 Mart 2019.

Balkaş, Özer, İbn Batuta Seyahatnamesinden Seçmeler, (Haz. İsmet Parmaksızoğlu), Millî Eğitim Basımevi, Ankara 1971.

Bayındır, Şükrü, "XX. Yüzyıl Sorunu: Benzin", Silahlı Kuvvetler Dergisi, nr. 278, Haziran 1981, ss. 63-81.

Besbelli, Saim, "Bir Damla Petrol, Bir Damla Kan", Ordu, nr. 165, Mart 1953, ss. 96-103.

Bowell, Tracy, Kemp, Gary, Eleştirel Düşünme Kılavuzu, (Trc. Bilge Tanrıseven), Tübitak Yay., Ankara Eylül 2018.

Bürün, Vecdi, "Afganistan Unutuldu mu?", Olaylara Bakış, nr. 17, 13-20 Ocak 1984, s. 19.

Çeliker, Fahri, "Stratejik Bölge Olarak Akdeniz", Stratejik Etütler Bülteni, nr. 71, Temmuz 1980, ss. 43-52.

Danişmend, İsmail Hami, Türklük Meseleleri, 2. b., İstanbul Kitabevi Yay., İstanbul 1983.

Darbouche, Hakîm, vd., "East MediterraneanGas: WhatKind of a game-Changer", The Oxford Institüte for Energy Studies, NG 71, December 2012.

Davıes, Norman, Avrupa Tarihi: Doğu'dan Batıya, Buz Çağından Soğuk Savaşa, Urallar'dan Cebelitarık'a, Avrupa'nın Panoraması, (Trc. Ed. Mehmet Ali Kılıçbay), İmge Kitabevi Yay., Ankara 2006.

Dayı, S. Esin, "Hatay Devleti ve Hatay'ın Anavatan'a Katılması", Atatürk Üniversitesi Türkiyat Araştırmaları Enstitüsü Dergisi, nr. 19, 2002, ss. 331-340.

Demiray, Muhittin, "Türkiye'nin Dış Politikasında Tahteveralli Denge Politikası ve Avrupa Birliği'nin Türkiye'nin Dış Politikasına Bakış1: Ortadoğu Örneği", Değişen Ortadoğuda Kültür ve Siyaset, (Ed. Yasin Aktay vd.), Stratejik Düşünce Enstitüsü Yay., Ankara Mart 2012, ss. 683-709.

Demirel, Bedrettin, "Bir Damla Kan, Bir Damla Petrol", Silahlı Kuvvetler Dergisi, nr. 236, Aralık 1970, ss. 35-37.

Duman, Hasan, Kültür Stratejileri ve Millı̂ Kültür Politikamız (Bir Bürokratın Çırpınışları), Enformasyon ve Dokümantasyon Hizmetleri Vakfı Yay., Ankara 2008.

Erdem, Turhan, "Harbin Kanı Petrol", Silahlı Kuvvetler Dergisi, nr. 252, Aralık 1974, ss. 90-99.

Fendoğlu, Hasan Tahsin, "Türk Dış Politikasında Kıbrıs", Uluslararası Boyutlarıyla Kıbrıs Meselesi ve Geleceği Uluslararası Sempozyumu 11-13 Aralı 2014 Gazimağusa: Bildiriler, (Haz. Duygu Türker Çelik), ATAM Yay., Ankara 2016, ss. 99-130

Gonca, Zeki, "Petrolün Dünya Politikasına Etkisi", Stratejik Etütler Bülteni, nr. 33, Ekim 1972, ss. 51-57.

Gökdağ, Bilgehan Atsız, "Orta Doğu'daki Türk Varlığı", Yeni Türkiye, nr. 82, Ocak-Haziran 2016, ss. 151-166.

Gurulkan, Kemal vd., Osmanlı Belgelerinde Kırım Savaşı (1853-1856), Başbakanlık Devlet Arşivleri Genel Müdürlüğü Yay., Ankara 2006.

Güneş, Mehmet, Arslan, Tayfun, "Enerji Bağımlığında Avrupa Birliği, Rusya, Türkiye Üçgeni ve Doğu Akdeniz Alanı", International Journal of Humanities and Education, IV, nr. 7, 2018, ss. 32-60.

Gürkan, Nezire, Zirvedeki Yalnızlık Kulesi: Rauf Raif Denktaş, Cümbez Yay.,Gazimagosa 2005.

Heyd, W., Yakın Doğu Ticaret Tarihi, (Trc. Enver Ziya Karal), Türk Tarih Kurumu Yay., Ankara 1975.

Hottınger, Arnold, "İsrail Cephesi ve 'Petrol Silahı' Arasında Arap Dünyası", Stratejik Etütler Bülteni, nr. 39, Ekim 1973, ss. 54-62.

Hür, Halit, "Stratejik Kavşak Noktası Olan Doğu Akdeniz'de Yürütülen Enerji Politikaları ve Türkiye", International Social Sciences Studies Journal, V, (30), February 2019, pp. 655-663.

Jacques, Chantaux, "İran-Irak Savaşı'nın Denizlerdeki Görüntüsü ve Ortadoğu'daki Petrol Trafiğinin Geleceği", (Trc. Hüseyin Işık), Silahlı Kuvvetler Dergisi, nr. 294, Kasım 1984, ss. 58-63.

James, A.,Keeping the Peace in the Cyprus Crises of 1963-64, Palgrave, Newyork 2002.

Jowed, Garth S., O'donnel, Victorya, Propaganda andPersiasion, California 1992.

Kafesoğlu, İbrahim, "Kıbrıs Faciası ve Tarih", Öğretmen, nr. 216, 25 Ocak 1967, s. 4-5, 7.

Karal, Enver Ziya, Osmanlı Tarihi, V, Türk Tarih Kurumu Yay., Ankara 1988.

Kavuncu, Orhan, "Türkiye'deki Türkistanlılar", Türk Yurdu, nr. 308, Nisan 2013, ss. 80-82. 


\section{T. Akkoyun}

Kayaltepe, Alpaslan, "Propaganda", Ordu, nr. 173, Mart 1954, ss. 10-15.

Keçili, Songül, “Tarihçilik Açısından Büyük Taarruz Sahasının Ekoturizm ile İlişkilendirilmesi”, Karabük Üniversitesi Sosyal Bilimler Enstitüsü Dergisi, VIII, nr. 1, 2018, ss. 116-128.

Kedikli, Umut, Deniz, Taşkın, "Enerji Kaynakları Mücadelesinde Doğu Akdeniz Havzası ve Deniz Yetki Alanları Uyuşmazlığı", Alternatif Politika, VII, nr. 3, Ekim 2015, ss. 399-424.

Kızmaz, Zahir, "Çatışma, Terör ve Savaşın Çocuklar Üzerindeki Etkisi", Şiddet ve Sosyal Travmalar, III, (Ed. Adem Solak), HEGEM Yay., Ankara 2018, ss. 1-19.

Kodaman, Bayram, Abdülhamid Devri Eğitim Sistemi, ÖtükenNşr., İstanbul 1991.

Kovancilar, Birol, Hayat Bir Pazar Yeri, Liberte Yay., Ankara Ocak 2011.

Kurşun, Zekeriya vd., Tarih Metodu, 7. b., (Ed. Zekeriya Kurşun), Anadolu Üniversitesi Yay., Eskişehir Ocak 2016.

Menoncourt, Jacgues, "Doğu Akdeniz'de Tehlikeli Türk-Yunan Rekabeti", Stratejik Etütler Bülteni, nr. 57, Ekim 1976, ss. 18-29.

Mutluçağ, Hayri, "İngiltere'nin Ortadoğu ve Türkiye Hakkında Gizli Emelleri", Belgelerle Türk Tarihi Dergisi, nr. 26, Kasim 1969, ss. 51-55.

Özkan, Cemal, "Afgan Direnişi Karşısında Hür Dünya", Silahlı Kuvvetler Dergisi, nr. 302, Mart 1986, ss. 30-38.

Sakınç, Metin, "Türkiye'nin Ulusal Güvenlik Stratejisi ve Doğu Akdeniz", Yerli Düşünce, nr. 58, Ekim 2019, s. $28-29$.

Saltıkgil, Halûk V., "Dünyada ve Türkiye'de Petrol: Ateşe Tapanlardan Petrole Tapanlara", Belgelerle Türk Tarihi Dergisi, nr. 29, Şubat 1970, ss. 43-50.

Singh, P., "Conceptual Understanding of Geopolitics with Special Reference toIndian Ocean", IJAR, I(6), 2015, pp. 282-284.

Soysal, İsmail, Tarihçeleri ve Açıklamaları ile Birlikte Türkiye'nin Siyasal Antlaşmaları (1920-1945),I, Türk Tarih Kurumu Yay., Ankara 1983.

Şahin, Hasan, "Doğu Sorunu Çerçevesinde Osmanlı-Fransız İlişkileri [Başlangıcından Paris Barışı'na (1856)]", Atatürk Üniversitesi Türkiyat Araştırmaları Enstitüsü Dergisi, nr. 40, 2009, ss. 277-315.

Şehrengiz, "100 Yıl Sonra Kıta Aşan Projelerle Afyon Şehrengizi", 09.04.2015 www.tdmmb.org.tr erişim 27 Ağustos 201918.53

Şenuyar, Vahit, "Süveyş Kanalının Önemi", Silahlı Kuvvetler Dergisi, nr. 227, 1968, ss. 48-51.

Şehsuvaroğlu, Lütfi, Mehmet Âkif: Belgeleriyle Milli Şairin Portresi, 3.b., Hasret Yay., Ankara 2017.

Turan, Önder, Kıbrıs'ta Ak Günlere, 2. b., Milliyetçi Yay., İstanbul 1974.

Türe, İlknur, "Amerikan Tarihini Farklı Okumak: Kuruluş ve Anayasa Tarihine Alternatif Bir Bakış", Türkiye Günlügüu, nr. 137, Kıș 2019, ss. 80-94.

Türe, İlknur,"Türkiye'nin Çevresi Ateşten Gömlek", Cumhuriyet, 17 Aralık 2000.

Türköne, Mücahit, "Gönüller Sultanı: Kudüs", Yerli Düşünce, nr. 25, Ocak 2017, ss. 92-94.

Türköne, Mücahit, "Uluslararası Bilim ve Teknoloji Konferansı Kapanış Bildirgesi", Yeni Türkiye Stratejik Araştırma Merkezi, 3-6 Ekim 2016, s. 1-2.

Ünalp, F. Rezzan, "İlklerin Savaşı: Kırım Savaşı (1853-1856)", Askerî Tarih Araştırmaları Dergisi, nr. 22, 2013, ss. 117.

Webster, Donald Everet, The Turkey of Atatürk: Social Process in the Turkish Reformation, The American Academy of Political and Social Science, Philadelphia 1939.

Yaşar, Ergül, "Doğu Akdeniz'de Petrol Oyunu", İskenderun Teknik Üniversitesi Haber Merkezi Bülteni, 2016, s. 1-2.

Yaycı, Cihat, "Doğu Akdeniz'de Deniz Yetki Alanlarının Sınırlandırılması Sorunu ve Türkiye", Bilge Strateji, IV, nr. 6, 2002, ss. 1-70.

Yıldız, Dursun, Doğu Akdeniz'de Isınan Sular, Bizim Kitaplar Yay., İstanbul 2009.

Yiğit, Ali, "Ortadoğu, Enerji ve Savaş", TMMOB EMO Ankara Şubesi Haber Bülteni, nr. 2, 2013, ss. 10-13. 